\title{
Chemical, biochemical, and microbiological aspects of chitosan quaternary salt as active coating on sliced apples
}

\author{
Aspectos químicos, bioquímicos e microbiológicos de sais quaternários de quitosana para revestimento \\ ativo de maçãs fatiadas
}

\author{
Douglas de $\mathrm{BRITTO}^{1 *}$, Odilio Benedito Garrido ASSIS ${ }^{1}$
}

\begin{abstract}
The biocompatibility of chitosan and chitosan quaternary salt coatings was evaluated for use as edible coatings for sliced apple. Measurement of water loss, color change, and fungal growth appearance were monitored as a function of time. A significant brownish effect was observed on chitosan coated slices, varying greatly from $L^{*}=76.5$ and Hue angle $=95.9^{\circ}(t=0)$ to $L^{*}=45.3$ and Hue angle $=69.8^{\circ}(t=3$ days), whilst for TMC coated samples the variation was considerable lower $\left(\mathrm{L}^{*}=74.1\right.$; Hue angle $\left.=95.0^{\circ}\right)$ to $\left(\mathrm{L}^{*}=67.0\right.$; Hue angle $\left.=83.8^{\circ}\right)$ within the same period. The hydrosoluble derivative $\mathrm{N}, \mathrm{N}, \mathrm{N}$-trimethylchitosan demonstrated good antifungal activity against $P$. expansum although highly dependent on the polymer properties such as degree of quaternization. The most efficient formulation was that prepared from derivative having a degree of quaternization of $45 \%$, high solubility, and high viscosity. This formulation restrained fungus spreading up to $30 \%$, while for the control it reached almost $80 \%$ of the total assessed surfaces during 7 days of storage.

Keywords: trimethyl chitosan; quaternary salts; antifungal; minimally processed food; edible coating.
\end{abstract}

\section{Resumo}

A biocompatibilidade de revestimentos baseados em quitosana e seus sais quaternários foi estudada visando seu emprego como revestimentos comestíveis de maçãs fatiadas. Medidas de perda de água, mudança de coloração e desenvolvimento de fungos foram monitoradas em função do tempo de estocagem. O efeito de escurecimento enzimático para fatias de maçãs recobertas com solução de quitosana foi bastante pronunciado, variando de $\mathrm{L}^{*}=76,5$ e Ângulo de Hue $=95,9^{\circ}(\mathrm{t}=0)$ a $\mathrm{L}^{*}=45,3$ e Ângulo de Hue $=69,8^{\circ}(\mathrm{t}=3$ dias $)$, ao passo que, para as amostras revestidas com TMC, a variação foi bem menor no mesmo período $\left(L^{*}=74,1\right.$; Ângulo de Hue $\left.=95,0^{\circ}\right)$ a $\left(L^{*}=67,0 ; \hat{A}^{*}\right.$ gulo de Hue $=83,8^{\circ}$ ). O derivado hidrossolúvel $\mathrm{N}, \mathrm{N}, \mathrm{N}$-trimetilquitosana apresentou ótima atividade antifúngica contra $P$. expansum, mas muito dependente das propriedades do polímero como o grau de quaternização. A formulação mais eficiente foi a preparada a partir do derivado com grau de quaternização de $45 \%$ com altas solubilidade e viscosidade. Neste caso, o avanço do fungo ficou restrito a cerca de $30 \%$, enquanto que para o controle atingiu-se cerca de $80 \%$ da superfície analisada para um período de 7 dias de armazenamento.

Palavras-chave: trimetil quitosana; sais quaternários; antifúngico; alimento minimamente processado; cobertura comestível.

\section{Introduction}

The development of new and natural products to prolong the shell-life of foods has been stimulated by a growing consumer demand for healthy, residue-free fresh products and also concern on ecological packaging (BOTREL et al., 2007; $\mathrm{NO}$ et al., 2007). One of the potential alternatives to conventional packaging which has received considerable attention in recent years is the use of biodegradable edible coatings applied directly to fruit and vegetables (JANJARASSKUL; KROCHTA, 2010; SHAHIDI; ARACHCHI; JEON, 1999; ASSIS; PESSOA, 2004), primarily to minimize the deterioration of so-called 'minimally processed food' (FONTES et al., 2008; KIM; SMITH; LEE, 1993; DUTTA et al., 2009).

Amongst several coating formulations already proposed, chitosan-based ones have received increasing interest due to their unique properties. Chitosan, as well its derivatives, is a class of nontoxic biopolymer that shows easy film forming ability, has antifungal activity, and promotes host defense responses in plant tissues, both in pre and post-harvest products (BANOS et al., 2006; NO et al., 2007). Several authors have reported the beneficial effects of this biopolymer as an edible film used to increase the shell-life of strawberries (MUNOZ et al., 2008), apples (CANAVER; DI PIERO, 2011; EL-GHAOUTH; SMILANICK; WILSON, 2000; EL-GHAOUTH et al., 2000; YU; LI; ZHENG, 2007), litchi fruits (ZHANG; QUANTICK, 1997), murcott tangors (CHIEN; SHEU; LIN, 2007), breadfruits (WORRELL; CARRINGTON; HUBER, 2002), and several others species (BAÑOS et al., 2006; NO et al., 2007; WIN et al., 2007). At the same time, the antimicrobial activity and mode of action against fungi, bacteria, and viruses, as well as the ability to elicit plant defense mechanisms have been well documented (LAUZARDO; VALLE; SANCHEZ, 2011; RABEA et al., 2003; BAÑOS et al., 2006).

Particularly for chitosan, for an effective coating, the $\mathrm{pH}$ solubility dependence is considered a challenge since this 
polymer is soluble only in moderately acidic aqueous solutions. However, at low $\mathrm{pH}$, the biocompatibility between the coating and the food surface is significantly reduced and degradative reactions may easily occur affecting both color and flavor, especially when applied to cut surfaces. In order to improve the solubility of chitosan in a neutral medium, chemical modifications have been proposed in the polymer backbone generating quaternized salt derivatives (BRITTO; ASSIS, 2007a). The biocompatibility of this modified chitosan is expected to be enhanced, and in this paper it was evaluated as a coating on minimally processed apples. Weight loss, browning effect, and the fungal growth as a function of time were assessed and compared with commercial chitosan and uncoated samples.

\section{Materials and methods}

\subsection{Chitosan and derivatives}

The alkylation of chitosan was carried out by reacting it with appropriate aldehyde followed by reduction with sodium cyanohydroborate. For the quaternization reaction, chitosan and alkylated chitosan were then reacted with dimethylsulfate in an alkaline medium. Medium molecular weight chitosan (MMW Chi, degree of acetylation, $\overline{D A}=18 \%$ ) was supplied by Sigma-Aldrich Corp. (St. Louis, MO, USA). Both the alkylation and the quaternization of chitosan have been previously described in detail (BRITTO; ASSIS, 2007a, b).

The alkylation of chitosan produced the derivatives $\mathrm{N}$-butylchitosan, N-octylchitosan, and N-dodecylchitosan, which were named ButChi, OctChi and DodecChi, respectively. The extensive methylation of the chitosan and the alkylchitosan derivatives via dimethylsulfate route resulted in the quaternary salts $\mathrm{N}, \mathrm{N}, \mathrm{N}$-trimethylchitosan, N-butyl$\mathrm{N}, \mathrm{N}$-dimethylchitosan, N-octyl-N,N-dimethylchitosan, and $\mathrm{N}$-dodecyl-N,N-dimethylchitosan, which were identified as TMC, ButDMC, OctDMC and DodecDMC, respectively.

Samples were characterized by Nuclear Magnetic Resonance spectroscopy (NMR) as following: The ${ }^{1} \mathrm{H}$ NMR spectra were acquired at $353 \mathrm{~K}$ using a $200 \mathrm{MHz}$ spectrometer (Bruker $\mathrm{AC200})$. Chitosan and derivatives were dissolved in $\mathrm{D}_{2} \mathrm{O} / \mathrm{HCl}$ $(100 / 1 \mathrm{v} / \mathrm{v})$ and in $\mathrm{D}_{2} \mathrm{O}$, respectively, at a concentration of $10 \mathrm{mg}$. $\mathrm{mL}^{-1}$. The solid-state CP-MAS ${ }^{13} \mathrm{C}$ NMR experiments were performed on a Varian Unity Inova 400 spectrometer operating at $400 \mathrm{MHz}$ for ${ }^{1} \mathrm{H}$ frequency, using the combined techniques of proton dipolar decoupling (DD), magic angle spinning (MAS), and cross-polarization (CP). Additional details are described elsewhere (BRITTO; ASSIS, 2007a, b).

\subsection{Fungus isolation and solutions for coating}

Common apples pathogens like Botrytis cinerea and Penicillium expansum were isolated from decayed apples, replicated, and cultured on PDA medium (extract of $200 \mathrm{~g}$ of boiled potato, $20 \mathrm{~g}$ of glucose and $20 \mathrm{~g}$ of agar in $1000 \mathrm{~mL}$ of distilled water) at $28{ }^{\circ} \mathrm{C}$ in darkness. Spore suspensions were prepared by flooding 7-day-old sporulating cultures with sterile Tween 80 solution $(1 \% \mathrm{v} / \mathrm{v})$. Spore counts were performed in a Neubauer chamber.
The solutions of chitosan and chitosan quaternary salts were prepared at $\mathrm{C} \approx 2 \mathrm{~g} \cdot \mathrm{L}^{-1}$ in aqueous acetic acid solution $(1 \% \mathrm{v} / \mathrm{v})$ and distilled water, respectively. To these solutions, $500 \mu \mathrm{L}$ of the spore suspension were added, and the final concentration was $1.0 \times 10^{6}$ spores. $\mathrm{mL}^{-1}$. A control solution was also prepared in the same way, except for the addition of chitosan or quaternary salts.

\subsection{Fungi growth, brownish, and weight loss measurements}

The apples (cv. Gala, Malus domestica) were acquired from the local market and selected according to size and visual aspect. Prior to being sliced, they were washed with detergent and tap water. The activity of the coating films against fungal growth was evaluated by dipping half sliced apples into the coating solutions for 30 seconds. The excess of solution was allowed to drain off, and the samples were exposed to spontaneous drying. The experiments were conducted in triplicate, and 10 apples (20 samples) were used in each experiment. A control experiment was carried out by dipping the sliced apple into the control solution. The apples were stored in a greenhouse $\left(28^{\circ} \mathrm{C}\right.$, humidity of $\left.80 \%\right)$ and fungal growth was monitored as a function of time. Pictures of the cut apples surfaces were individually scanned using a commercial scanner or digital camera. The acquired images were directly imported into an image processing software (ImageJ $1.40 \mathrm{~g}$, Wayne Rasband, National Institutes of Health, USA), providing a visual history and track alterations of the surfaces. A two dimensional growth was assumed, and the results were expressed as the percentage of the blackness proportionally to each slice area.

The brownish effect (resulting from fruit spoilage) was monitored using a separate batch of experiments in which the spore solution was not added to the coating solution. The color variation was measured directly on the cut apple endosperm using a Chroma Meter CR-400, Konica Minolta. The color was recorded using CIE- $\mathrm{L}^{*}, \mathrm{C}^{*}$, and $\mathrm{H}$ values, standing for luminosity, Chroma, and Hue angles, respectively.

Loss of mass was estimated by daily weighing the coated and uncoated samples in a separate set of experiments. The recorded data was the average of four independent measurements.

\section{Results and discussion}

\subsection{Chemical characteristics}

Evidence for the occurrence of $\mathrm{N}$-methylation is seen in the region $2.4<\delta<3.3$ in the ${ }^{1} \mathrm{H}$ NMR spectrum (Figure 1). The signal developed at $3.0 \mathrm{ppm}$ is assumed to be referenced to the $\mathrm{N}, \mathrm{N}$-dimethylated sites, and the signal at $3.25 \mathrm{ppm}$ is related to the occurrence of quaternization (BRITTO; ASSIS, 2007a, b). Figure 1 also shows two signals at 3.45 and 3.36, both of which are assigned to the O-methylated sites. The signal at $1.99 \mathrm{ppm}$ corresponds to the hydrogen atoms of the methyl moieties of the acetamido groups.

The CP-MAS ${ }^{13} \mathrm{C}$ NMR spectroscopy enables a good understanding of the chitosan derivative structure (Figure 2). Main characteristic signals are (BRITTO; ASSIS, 2007a, b): a) $\delta=36.6 \mathrm{ppm}$ attributed to carbon atoms of $\mathrm{N}$-monomethylated; 


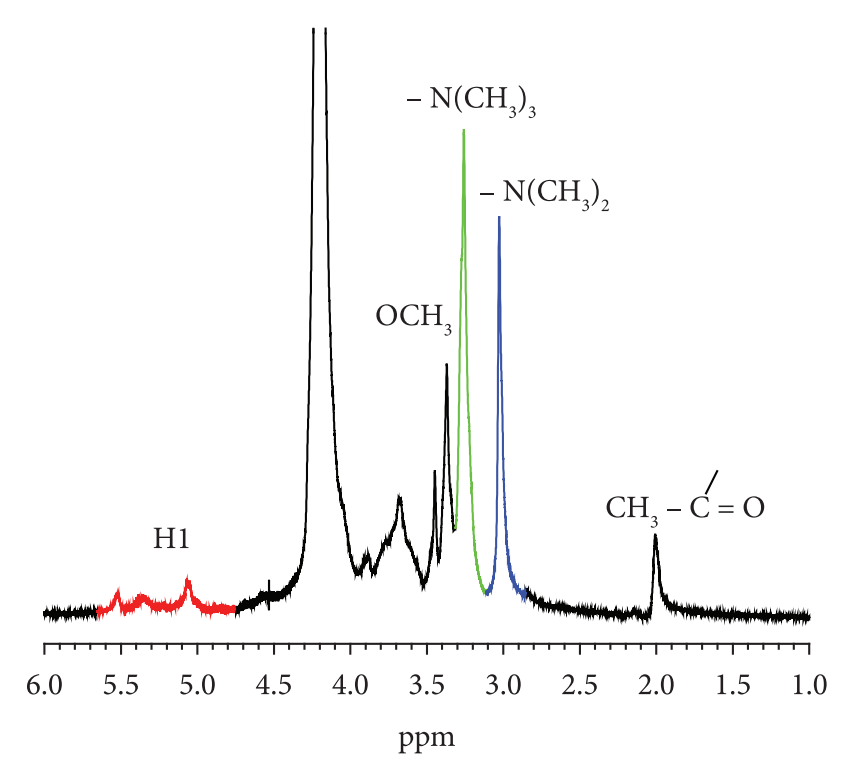

Figure 1. Typical ${ }^{1} \mathrm{H}-\mathrm{NMR}$ spectrum of a chitosan quaternary salt (TMC) dissolved in $\mathrm{D}_{2} \mathrm{O}$.

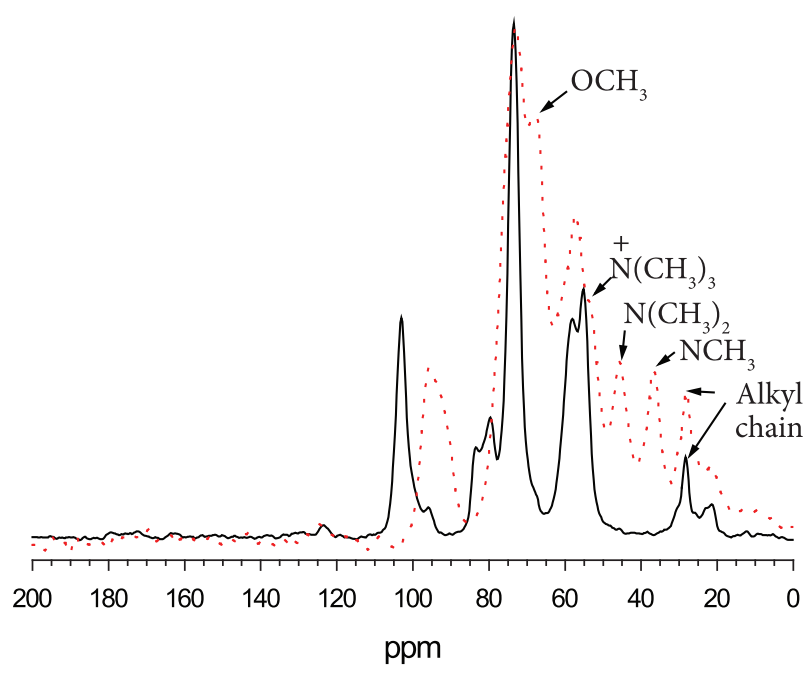

Figure 2. Typical CP-MAS ${ }^{13} \mathrm{C}$ NMR spectra of alky chitosan derivatives showing DodecChi (—) and its quaternary salt DodecDMC $(\ldots \ldots \ldots)$.

b) $\delta=45.6 \mathrm{ppm}$, which correspond to carbon atoms of $\mathrm{N}, \mathrm{N}$-dimethylated groups; $\mathrm{c}), \delta=53.5 \mathrm{ppm}$ attributed to carbon atoms of $\mathrm{N}, \mathrm{N}, \mathrm{N}$-trimethylated groups, and d), and $\delta=67.9 \mathrm{ppm}$ representing the carbon atoms in the $\mathrm{O}$-methylated groups. This has allowed us to calculate the degrees of alkyl substitution and quaternization. For ButChi, OctChi and DodecChi, the degree of substitution was 103,27 and $3 \%$, respectively.

Concerning the mechanical properties, previous DMA measurements indicated that chitosan and its derivative films are typically brittle materials, exhibiting similar nonlinear viscoelastic behaviors (BRITTO; ASSIS, 2007a). For example, according to such study, films of unmodified chitosan had a very small strain, near 2.8\%, but showed high resistance with Young's modulus of 2,283 MPa. On the other hand, the referred study also showed that the alkyl chitosan derivatives appeared to be more plastic but less resistant than chitosan films. Therefore, for N-butyl-N,N-dimethylchitosan the strain reached $13.1 \%$ with Young's modulus close to $171 \mathrm{MPa}$.

The introduction of alkyl chain and the promotion of quaternization in chitosan structure make it possible to obtain water soluble derivatives with different hydrophilic characteristics (BRITTO; ASSIS, 2010). Contact angle and wetting analyses in films cast from these materials indicated a strong relationship between functional group polarity and water or ethanol affinity. In addition, according to the referred study, the cast films of chitosan showed good homogeneity showing low roughness and regular distribution over a polar surface. On the other hand, alkyl quaternary salts, e. g., OctDMC, showed an irregular topography with undulation and mountain-like formation probably due to agglomeration of polymeric chains. The final film morphology was dependent on the polymer solubility, as observed by microscopic techniques.

\subsection{Biocompatibility}

Chitosan and its derivatives act against loss of water despite their hydrophilic character. The results showed that for slices coated with chitosan, TMC and DodecDMC, the weight loss was lower than that of the control samples (Figure 3). Similar results are found in the literature, in which cut apples coated with chitosan films retain approximately $55 \%$ of the original weight on the eleventh day of storage, compared to $40 \%$ measured in the control sample (ASSIS; PESSOA, 2004). More concentrated precursor solutions $\left(C=10-20\right.$ g. $\left.\mathrm{L}^{-1}\right)$ usually have greater efficiency in reducing weight loss since a high concentration of polymer forms a thicker film and provides a better physical barrier against water vapor permeation (ZHANG; QUANTICK, 1997; McHUGH; SENESI, 2000). However, the use of concentrated formulations would increase processing cost and introduce additional difficulties in dipping (due to an increase in solution viscosity) and may reduce antifungal activity. Moreover, the ability to reduce the loss of water depends on the kinds of peel and cut tissue. Zhang and Quantick (1997) conducted studies with Chinese litchi fruit and found no significant difference in weight loss between the control and a chitosan coated sample. A similar result was found by Worrell, Carrington and Huber (2002) in studies with breadfruit coated with chitosan: the difference between the control and the chitosan coated sample was less than $10 \%$ on the twelfth day of storage. In a study with strawberries, the difference between the control and the chitosan coated fruits was just 8\% (MUÑOZ et al., 2008). Better results may be achieved when lipids (monoglycerides or triglycerides) are incorporated in the coating formulation, as reported by Olivas, Mattinson and Cánovas (2007). An important feature of any coating is the ability to reduce weight loss due to water vapor transpiration. Water loss influences the texture and is a major factor influencing overall appearance and texture and, thus, consumer acceptance (OLIVAS; MATTINSON; CÁNOVAS, 2007). In order to slow down softening rate, calcium dips are widely used (OLIVAS; MATTINSON; CÁNOVAS, 2007; 
MUÑOZ et al., 2008). Calcium ions interact with the pectin of the apple tissue to form a cross-linked polymer network that increases mechanical strength and prevents enzymatic deterioration. A similar effect can be, in principle, expected to occur between the chitosan or TMC and the pectin due to its poly-cationic nature.

The browning effect was evaluated by measuring $L^{*}$ (lightness) and Hue angle. The sharp decrease of $\mathrm{L}^{*}$ observed for chitosan coated samples (Figure 4a) evidences the occurrence of progressive surface darkening. On the other hand, for TMC coated samples (Figure $4 \mathrm{a}$ ), the rate of $\mathrm{L}^{*}$ decrease was considerable lower than that of chitosan coated samples evidencing the TMC ability to reduce the brownish

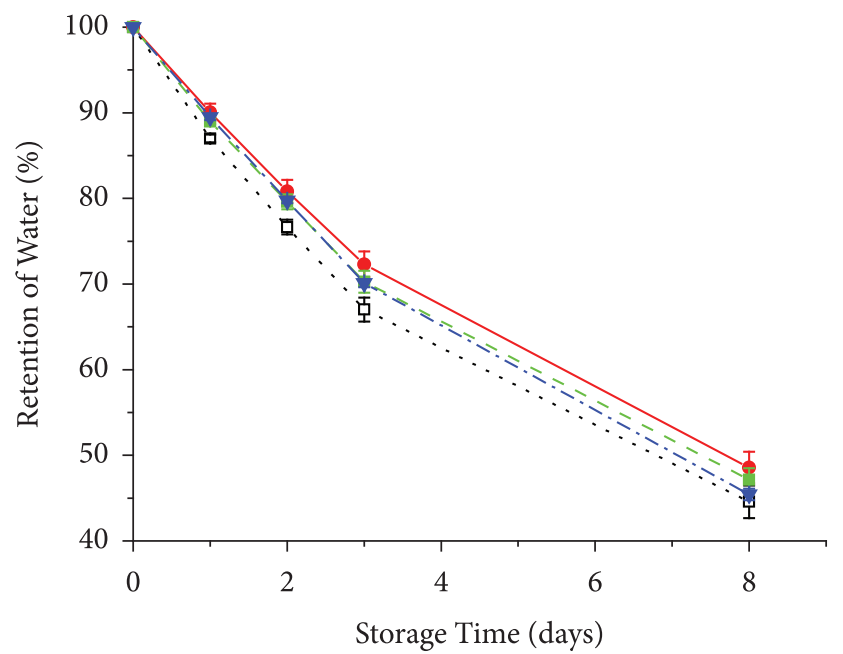

Figure 3. Typical average water retention profile during storage for cut apples coated with film of chitosan $(\bullet)$; TMC $(\boldsymbol{\bullet})$; DodecDMC $(\boldsymbol{\nabla})$ compared with the control ( $\square) .\left(28^{\circ} \mathrm{C}, \mathrm{RH} 80 \%\right)$. effect. A similar behavior was found for Hue angle variation (Figure $4 \mathrm{~b}$ ). Both the chitosan and TMC coated samples shifted from $90^{\circ}$ yellow quadrant toward $0^{\circ}$ red quadrant, but the most sensible decrease was found for chitosan coated samples. Other quaternary salt solutions showed a similar behavior. In fact, water solubility is likely to be an important parameter in reducing the browning effect. The acid medium used for the preparation of chitosan solution catalyzes the oxidative degradation of polyphenol oxidase enzymes on the pericarp of the fruit and reduces the biocompatibility of the coating, deeply affecting the color and flavor. Therefore, the water solubility of chitosan quaternary salts represents an important improvement and offers potential applications within the minimally processed fruit area. In addition, it represents a potential alternative for anti-browning compounds, mainly sulfite-based compounds, which have been banned due to their toxicity (ROJAS-GRAÜ et al., 2007; BUTA et al., 1999).

Additionally, the stimulus $\mathrm{a}^{*}$, which indicates chromaticity on a green $(-)$ to red $(+)$ axis, shifted from negative values to more positive figures (data not shown), indicating a shift towards a red coloring. Chroma and stimulus $\mathrm{b}^{\star}$ (chromaticity on a blue $(-)$ to yellow $(+)$ axis) did not show any significant changes.

For certain fruits such as banana (WIN et al., 2007) and breadfruit (WORRELL; CARRINGTON; HUBER, 2002), the retardant effect of the chitosan coating on browning was reported to be insignificant, with no apparent beneficial effect. On the other hand, for litchi fruit (NO et al., 2007) and Chinese water chestnut (PEN; JIANG, 2003), chitosan coating showed a positive effect in preventing the browning.

Regarding the antifungal activity of the chitosan and its derivatives, a remarkable finding on the present study was the influence of the $\mathrm{pH}$ solution on the antifungal activity (Figure 5). For P. expansum, the percentage of fungal growth was higher for (a)

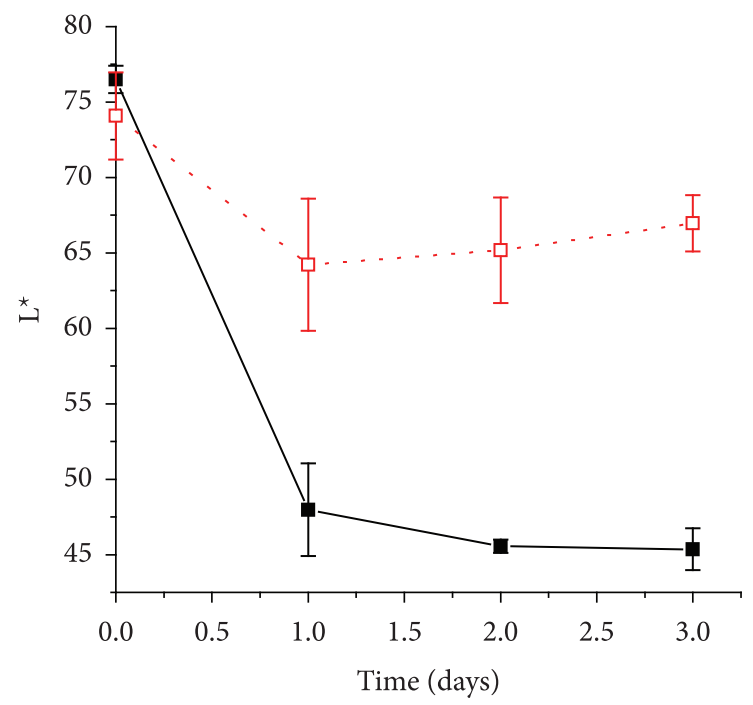

(b)

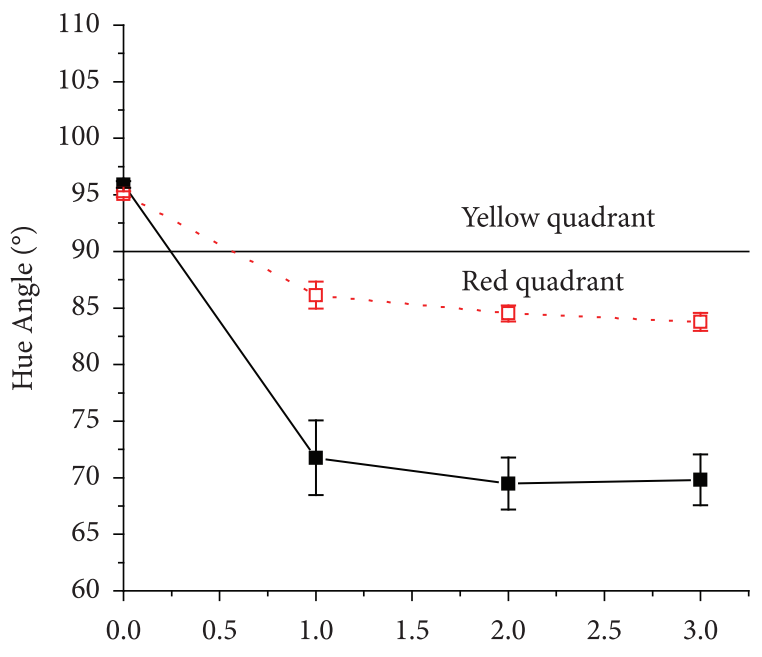

Figure 4. Typical variation of a) $L^{*}$ and b) Hue angle values as a function of time for the apple pericarp coated with chitosan ( $\square$ ) and TMC ( $\square$ ) solutions. 


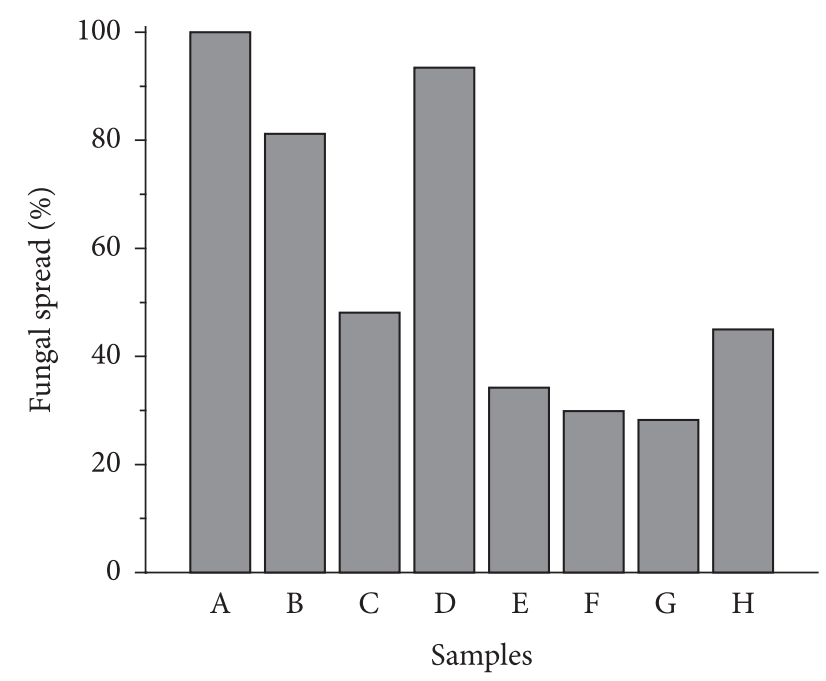

Figure 5. P. expansum colonies development on cut apple surface coated with different coating solutions after 7 days of storage in a greenhouse at $28{ }^{\circ} \mathrm{C}$ and $80 \%$ humidity. Caption: A) acetic acid control; B) water control; C) chitosan; D) TMC1; E) TMC2; F) ButDMC; G) OctDMC and $\mathrm{H})$ DodecDMC.

acetic acid solution (acid control) than for water (water control). It is clear that the acid condition is favorable for the development of $P$. expansum colonies on the cut apple surface. However, when chitosan is present, the inhibition of the $P$. expansum colonies is evident (Figure 5). In fact, the activity of the chitosan is noticeable even in the acidic condition, which is a favorable medium for fungal development. The mechanism model for the inhibitory action of the chitosan is still uncertain, but the occurrence of electrostatic interactions involving the positively charged chitosan molecules and the negatively charged surface of the fungal cell is possibly important, as well as the occurrence of chelation of metals, suppression of spore elements, and the binding of chitosan to essential nutrients for fungal growth (GOY; BRITTO; ASSIS, 2009).

In fact, Yu, Li and Zheng (2007) found that the chitosan coating was effective against $P$. expansun spore germination in vitro and in vivo when introduced on the wound of a Fuji apple (Malus domestica Borkh.). According to them, for the in vitro test, a complete inhibition of the fungus $P$. expansum spore germinations was achieved when the chitosan concentration was $0.3 \%$. For the in vivo test, the treatment with chitosan at the highest concentration $(\mathrm{C}=1 \%)$ and the lowest viscosity $(\eta=12 \mathrm{cP})$ was the most effective. Another important finding is that the combination of Cryptococcus laurentii (a yeast antagonist) and chitosan solution $(\mathrm{C}=0.1 \%)$ especially with low viscosity $(\eta<12 \mathrm{cP})$ brought about a synergistic effect of inhibiting the blue mold rot when compared with the application of C. laurentii or chitosan alone. Adding essential oil (WILSON; EL-GHAOUTH; WISNIEWSKI, 2003) or using dilute solution of some organic acid, e.g., acetic, sorbic, propionic, lactic, and glutamic acid (WILSON; EL-GHAOUTH, 2002), has helped to improve the fungicide effect, and it may represent an actual alternative to synthetic fungicides such as thiabendazole or imazalil.
TMC showed important antifungal activity against P. expansum, which was strongly dependent on the characteristics of the polymer (Figure 5). Thus, comparing the samples TMC1 (degree of substitution of $18 \%$, low solubility and low viscosity) with TMC2 (degree of substitution of $45 \%$, high solubility and high viscosity), it was found that the latter presents better antifungal activity. The chitosan derivatives ButDMC, OctDMC, and DodecDMC also indicated good antifungal activity although only in an acidic medium (Figure 5). The introduction of alkyl substituents on the chitosan chain strongly decreases the polymer solubility, a property which seems to play a very important role in antifungal activity.

TMC exhibited moderate antifungal activity against the fungus $B$. cinerea, with fungus spreading of $45.5 \%$ as compared to the respective controls $51.5 \%$. As observed for P. expansum, the acetic acid medium was favorable for fungus spreading on cut apple surface, reaching values near $90 \%$.

Quaternary salts of chitosan have been tested against several bacteria such as Escherichia coli and Staphylococcus aureus (KIM et al., 1997; JIA; SHEN; XU, 2001; SUN et al., 2006), but regarding the action of chitosan quaternary salt against fungal spread there is no published data available. However, some chitosan derivatives such as N,O-carboximethyl chitosan (ELGHAOUTH et al., 1992) and glycolchitosan (EL-GHAOUTH; SMILANICK; WILSON, 2000; EL-GHAOUTH et al., 2000) have been tested. It was found that the $\mathrm{N}, \mathrm{O}$-carboximethylchitosan, a water soluble derivative, was less effective than chitosan in reducing the radial growth of the fungi $B$. cinerea and Rhizopus stolanifer, while glycolchitosan, an acid soluble derivative, was more effective than chitosan against the fungi $B$. cinerea and $P$. expansum. Thus, as already mentioned, it would appear that the fungicide effect depends on the charge density of the derivative chain.

\section{Conclusion}

The introduction of alkyl chain and the promotion of quaternization (via dimethylsulfate synthetic route) in the chitosan structure make it possible to obtain water-soluble derivatives with different hydrophilic characteristics, completely water-soluble, and easy to be cast into films in coating experiments. The beneficial use of water soluble quaternary salt of chitosan is clearly seen by its low browning effect on cut apple surface, representing a potential alternative for commercial hazardous anti-browning compounds. TMC showed important antifungal activity against $P$. expansum, while for $B$. cinerea it was moderated. The other quaternary salts, having alkyl chain moieties, showed good antifungal activity although only in an acidic medium.

\section{Acknowledgements}

This study was supported by FAPESP, CNPq and Embrapa.

\section{References}

ASSIS, O. B. G.; PESSOA, J. D. C. Preparation of thin films of chitosan for use as edible coatings to inhibit fungal growth on sliced fruits. Brazilian Journal of Food Technology, v. 17, n. 1, p. 17-22, 2004. 
BAÑOS, S. B. et al. Chitosan as a potential natural compound to control pre and postharvest diseases of horticultural commodities. Crop Protection, v. 25, n. 2, p. 108-118, 2006. http://dx.doi.org/10.1016/j. cropro.2005.03.010

BOTREL, D. A. et al. Qualidade de alho (Allium sativum) minimamente processado envolvido com revestimento comestível antimicrobiano. Ciência e Tecnologia de Alimentos, v. 27, n. 1, p. 32-38, 2007. http:// dx.doi.org/10.1590/S0101-20612007000100006

BRITTO, D.; ASSIS, O. B. G. Hydrophilic and morphological aspects of films based on quaternary salts of chitosan for edible applications. Packaging Technology and Science, v. 23, n. 2, p. 111-119, 2010.

BRITTO, D.; ASSIS, O. B. G. Synthesis and mechanical properties of quaternary salts of chitosan-based films for food application. International Journal of Biological Macromolecules, v. 41, n. 2, p. 198-203, 2007a. PMid:17399783. http://dx.doi.org/10.1016/j. ijbiomac.2007.02.005

BRITTO, D.; ASSIS, O. B. G. A novel method for obtaining a quaternary salt of chitosan. Carbohydrate Polymers, v. 69, n. 2, p. 305-310, 2007b. http://dx.doi.org/10.1016/j.carbpol.2006.10.007

BUTA, J. G. et al. Extending storage life of fresh-cut apples using natural products and their derivatives. Journal of Agricultural Food Chemistry, v. 47, n. 1, p. 1-6, 1999. PMid:10563838. http:// dx.doi.org/10.1021/jf980712x

CANAVER, B. S.; DI PIERO, R. M. Quitosana e adjuvantes para o controle preventivo do mofo azul da macieira. Tropical Plant Pathology, v. 36, n. 6, p. 419-423, 2011. http://dx.doi.org/10.1590/ S1982-56762011000600013

CHIEN, P.-J.; SHEU, F.; LIN, H.-R. Coating citrus (Murcott tangor) fruit with low molecular weight chitosan increases postharvest quality and shelf life. Food Chemistry, v. 100, n. 3, p. 1160-1164, 2007. http://dx.doi.org/10.1016/j.foodchem.2005.10.068

DUTTA, P. K. et al. Perspectives for chitosan based antimicrobial films in food applications. Food Chemistry, v. 114, n. 4, p. 1173-1182, 2009. http://dx.doi.org/10.1016/j.foodchem.2008.11.047

EL-GHAOUTH, A. et al. Antifungal activity of chitosan on postharvest pathogens - Induction of morphological and cytological alterations in rhizopus-stolonifer. Mycological Research, v. 96, n. 9, p. 769-779, 1992. http://dx.doi.org/10.1016/S0953-7562(09)80447-4

EL-GHAOUTH, A. et al. Application of Candida saitoana and glycolchitosan for the control of postharvest diseases of apple and citrus fruit under semi-commercial conditions. Plant Disease, v. 84, n. 3, p. 243-248, 2000. http://dx.doi.org/10.1094/PDIS.2000.84.3.243

EL-GHAOUTH, A.; SMILANICK, J. L.; WILSON, C. L. Enhancement of the performance of Candida saitoana by the addition of glycolchitosan for the control of post harvest decay of apple and citrus fruit. Postharvest Biology and Technology, v. 19, n. 1, p. 103-110, 2000. http://dx.doi.org/10.1016/S0925-5214(00)00076-4

FONTES, L. C. B. et al. Conservação de maçã minimamente processada com o uso de películas comestíveis. Ciência e Tecnologia de Alimentos, v. 28, n. 4, p. 872-880, 2008. http://dx.doi.org/10.1590/ S0101-20612008000400017

GOY, R. C.; BRITTO, D.; ASSIS, O. B. G. A review of the antimicrobial activity of chitosan. Polímeros, v. 19, n. 3, p. 241-247, 2009. http:// dx.doi.org/10.1590/S0104-14282009000300013

JANJARASSKUL, T.; KROCHTA, J. M. Edible Packaging Materials. Annual Review of Food Science and Technology, v. 1, n. 1, p. 415418, 2010. PMid:22129343. http://dx.doi.org/10.1146/annurev. food.080708.100836
JIA, Z.; SHEN, D.; XU, W. Synthesis and antibacterial activities of quaternary ammonium salt of chitosan. Carbohydrate Research, v. 333 , n. 1, p. 1-6, 2001. http://dx.doi.org/10.1016/S00086215(01)00112-4

KIM, C. H. et al. Synthesis of chitosan derivatives with quaternary ammonium salt and their antibacterial activity. Polymer Bulletin, v. 38, n. 4, p. 387-393, 1997. http://dx.doi.org/10.1007/ s002890050064

KIM, D. M.; SMITH, N. L.; LEE, C. Y. Quality of minimally processed apple slices from selected cultivars. Journal of Food Science, v. 58, n. 5, p. 1115-117, 1993. http://dx.doi.org/10.1111/j.1365-2621.1993. tb06127.x

LAUZARDO, A. N. H; VALLE, M. G. V.; SANCHEZ, M. G. G, Current status of action mode and effect of chitosan against phytopathogens fungi. African Journal of Microbiology Research, v. 5, n. 2, p. 4243-4247, 2011.

McHUGH, T. H.; SENESI, E. Apple wraps: A novel method to improve the quality and extend the shelf life of fresh-cut apples. Journal of Food Science, v. 65, n. 3, p. 480-485, 2000. http://dx.doi. org/10.1111/j.1365-2621.2000.tb16032.x

MUÑOZ, P. H. et al. Effect of chitosan coating combined with postharvest calcium treatment on strawberry (Fragaria $x$ ananassa) quality during refrigerated storage. Food Chemistry, v. 110, n. 2, p. 428-435, 2008. http://dx.doi.org/10.1016/j.foodchem.2008.02.020

NO, H. K. et al. Applications of chitosan for improvement of quality and shelf life of foods: A review. Journal of Food Science, v. 72, n. 5, p. R87-R100, 2007. PMid:17995743. http://dx.doi.org/10.1111/ j.1750-3841.2007.00383.x

OLIVAS, G. I.; MATTINSON, D. S.; CÁNOVAS, G. V. B. Alginate coatings for preservation of minimally processed 'Gala' apples. Postharvest Biology and Technology, v. 45, n. 1, p. 89-96, 2007. http://dx.doi.org/10.1016/j.postharvbio.2006.11.018

PEN, L. T.; JIANG, Y. M. Effects of chitosan coating on shelflife and quality of fresh-cut Chinese water chestnut. Lebensmittel-Wissenschaft und-Technologie, v. 36, n. 3, p. 359-364, 2003.

RABEA, E. I. et al. Chitosan as antimicrobial agent: Applications and mode of action. Biomacromolecules, v. 4, n. 3, p. 1457-1465, 2003. PMid:14606868. http://dx.doi.org/10.1021/bm034130m

ROJAS-GRAÜ, M. A. et al. Apple puree-alginate edible coating as carrier of antimicrobial agents to prolong shelf-life of fresh-cut apples. Postharvest Biology and Technology, v. 45, n. 2, p. 254-264, 2007. http://dx.doi.org/10.1016/j.postharvbio.2007.01.017

SHAHIDI, F.; ARACHCHI, J. K. V.; JEON, Y.-J. Food applications of chitin and chitosans. Trends in Food Science \& Technology, v. 10, n. 2, p. 37-51, 1999. PMid:21299575. http://dx.doi.org/10.1016/ S0924-2244(99)00017-5

SUN, L. et al. Preparation, characterization and antimicrobial activity of quaternized carboxymethyl chitosan and application as pulp-cap. Polymer, v. 47, n. 6, p. 1796-1804, 2006. http://dx.doi.org/10.1016/j. polymer.2006.01.073

WILSON, C. L.; EL-GHAOUTH, A. Biological coating with a protective and curative effect for the control of postharvest decay. US 6,423,310 B1, 2002.

WILSON, C. L.; EL-GHAOUTH, A.; WISNIEWSKI, M. E. Synergistic combinations of natural of compounds that control decay of fruits and vegetables and reduce contamination by food borne human pathogens. US $20030113421 \mathrm{~A} 1,2003$. 
WIN, N. K. K. et al. Effects of cinnamon extract, chitosan coating, hot water treatment and their combinations on crown rot disease and quality of banana fruit. Postharvest Biology and Technology, v. 45, n. 3, p. 333-340, 2007. http://dx.doi.org/10.1016/j. postharvbio.2007.01.020

WORRELL, D. B.; CARRINGTON, C. M. S.; HUBER, D. J. The use of low temperature and coatings to maintain storage quality of breadfruit, Artocarpus altilis (Parks.) Fosb. Postharvest Biology and Technology, v. 25, n. 1, p. 33-40, 2002. http://dx.doi.org/10.1016/ S0925-5214(01)00143-0
YU, T.; LI, H. Y.; ZHENG, X. D. Synergistic effect of chitosan and Cryptococcus laurentii on inhibition of Penicillium expansum infections. International Journal of Food Microbiology, v. 114, n. 3, p. 261-266, 2007. PMid:17107729. http://dx.doi.org/10.1016/j. ijfoodmicro.2006.09.008

ZHANG, D.; QUANTICK, P. C. Effects of chitosan coating on enzymatic browning and decay during postharvest storage of litchi (Litchi chinensis Sonn.) fruit. Postharvest Biology and Technology, v. 12, n. 2, p. 195-202, 1997. http://dx.doi.org/10.1016/S09255214(97)00057-4 